\title{
İstilacı Ailanthus altissima (Mill.) Swingle (Simaroubaceae) Türünün Yaprak N ve P Rezorbsiyonu
}

Geliş / Received: 02/11/2020

\author{
Burak Sürmen ${ }^{1 *}$
}

Revize / Revised: 10/12/2019 Kabul/Accepted: 21/02/2020

ÖZ

$\mathrm{Bu}$ çalışmada, istilacı Ailanthus altissima (Mill.) Swingle türünün yaprak $\mathrm{N}$ ve $\mathrm{P}$ rezorbsiyon düzeyleri araştırılmıştır. Bunun için vejetasyon dönemi boyunca yaprak ve toprak örnekleri toplanmıştır. Böylece $\mathrm{N}$ ve $\mathrm{P}$ elementlerinin yapraklardan geri alınma miktarları ve bazı toprak özellikleriyle olan ilişkilerinin belirlenmesi amaçlanmıştır. Çalışma alanı olarak Sakarya ili Hendek ilçesinde tahribatın etkili olduğu ve türün giderek yayıldığı ormanlık alanlar seçilmiştir. Belirlenen alanlarda vejetasyon dönemi boyunca her ay türe ait yaprak ve toprak örnekleri alınmıştır. Alınan yaprak örneklerinde $\mathrm{N}$ ve $\mathrm{P}$ analizleri yapılarak türün olgun ve senesens dönemleri belirlenmiş ve rezorbsiyon miktarları hesaplanmıştır. Ayrıca toprak örneklerinin $\mathrm{N}$ ve $\mathrm{P}$ içerikleri ile pH ve elektriksel iletkenlik değerleri ölçülmüş ve rezorbsiyon miktarları ile olan ilişkileri açıklanmıştır. Elde edilen bulgulara göre türün $\mathrm{N}$ rezorbsiyon yeteneğinin yüksek düzeyde, $\mathrm{P}$ rezorbsiyon yeteneğinin ise sınır değerlere yakın olduğu bulunmuştur. Ayrıca farklı toprak özelliklerinin (besin içeriği, pH ve elektriksel iletkenlik) N ve P rezorbsiyon miktarlarını olumsuz etkilemediği tespit edilmiştir. Sonuç olarak, A. altissima düşük besin içerikli, farklı $\mathrm{pH}$ ve elektriksel iletkenlik değerlerine sahip alanlarda gelişebilmesi türün ağaçlandırma çalışmalarında kullanılmasının yanında yüksek besin içeriğine sahip bol miktarda ölü örtü üretmesi de toprağın $\mathrm{N}$ ve $\mathrm{P}$ bakımından zenginleşmesini sağlamaktadır.

Anahtar Kelimeler-Besin koruma stratejisi, Tahribat, Rekabet, Toprak özellikleri

1*Sorumlu yazar iletişim: buraksurmen@gmail.com (https://orcid.org/0000-0002-4055-613X)

Biyoloji Bölümü, Kamil Özdağ Fen Fakültesi, Karamanoğlu Mehmetbey Üniversitesi, Karaman, Türkiye 


\title{
Foliar N and P Resorption in Invasive Ailanthus altissima (Mill.) Swingle (Simaroubaceae) Species
}

\begin{abstract}
In this study, leaf $\mathrm{N}$ and $\mathrm{P}$ resorption levels of invasive Ailanthus altissima (Mill.) Swingle species were investigated. For this goal, leaf and soil samples were collected during the vegetation period. Thus, it was aimed to determine the amount of $\mathrm{N}$ and $\mathrm{P}$ elements from the leaves and their relationships with some soil properties. Forests in the Hendek district of Sakarya province which are affected by disturbance and species is gradually spread have been selected as the study area. Leaf and soil samples were collected every month during the vegetation period. The green and senescence periods of the species were determined by using $\mathrm{N}$ and $\mathrm{P}$ analyzes in the leaf samples taken and the resorption amounts were calculated. In addition, $\mathrm{N}$ and $\mathrm{P}$ contents, $\mathrm{pH}$ and electrical conductivity values of soil samples were measured and their relationships with resorption levels were explained. According to the findings, the $\mathrm{N}$ resorption ability of the species was found to be high and $\mathrm{P}$ resorption ability was close to the limit values. In addition, it was found that different soil properties (nutrient content, $\mathrm{pH}$ and electrical conductivity) did not adversely affect $\mathrm{N}$ and $\mathrm{P}$ resorption levels. As a result, $A$. altissima can be developed in areas with low nutrient content, different $\mathrm{pH}$ and electrical conductivity values, and so species can be used in plantation studies. Beside the abundance of litter with high nutrient content also enables the soil to enrich in $\mathrm{N}$ and $\mathrm{P}$.
\end{abstract}




\section{I.GİRIŞ}

Ağaç ve çalı formundaki bitkiler vejetatif dönemlerinin sonunda yapraklarındaki besin elementlerini gövdelerine taşırlar. Bu taşınma olayına "rezorbsiyon" veya "geri taşınım" denmektedir [1]. Odunsu bitkiler bu yolla bir sonraki vejetatif gelişimde yeni yaprakların oluşumu için gerekli besin elementlerinin büyük bir kısmını karşılar. Bu süreç içerisinde ise yapraklardaki azotun \%70'i ve kuru kütlenin \%60'ı dayanıklı dokulara taşınmaktadır [2,3]. Bu mekanizma özellikle ılıman iklim bölgelerinde olumsuz çevre koşullarına karşı odunsu bitkilerin kazanmış olduğu önemli bir özelliktir. Bu sayede olumsuz çevre şartlarında bile yaprak devamlılığı sağlanırken, bitkinin solunum için harcadığı enerjiden de tasarruf edilmiş olunur [4]. Bundan dolayı rezorbsiyon mekanizması yapraklardaki besin maddelerinin korunmasını sağladığı gibi ekosistem döngüsünde de çok önemi bir yere sahiptir. $[1,2,3]$. Özellikle besince fakir ortamlarda ağaç ve çalıların hayatlarını devam ettirmesi bakımından bu mekanizma çok önemlidir [5].

Azot ve fosfor elementleri büyüme ve gelişme döneminde dokular arasında yüksek mobiliteye sahip olup vejetatif dönemin sonunda ise rezorbsiyonun bir sonucu olarak mobiliteleri azalır [6]. Bilindiği üzere azot elementi proteinlerin yapısına katılırken, fosfor elementi ise hücresel enerji transferinde önemli rol oynar. Bununla birlikte her iki element nükleik asitlerin yapılarında yer alır $[7,8,9]$. Bu elementler orman ekosistemlerinde bitki büyümesinde sınırlayıcı role sahip oldukları gibi aynı zamanda senesens yapraklarından en çok geri alınan besin elementleridir [10]. Önemli görevlerinden dolayı bu iki element, rezorbsiyon çalışmalarında en çok araştırılan besin elementleridir.

Yaprak azotu $(\mathrm{N})$ ve fosfor $(\mathrm{P})$ miktarları ile beraber yapraklardaki N:P oranları rezorbsiyon miktarı ile yakından ilişkilidir $[11,12,13]$. Yaprak N:P oranlarının bilinmesi bu iki element tarafından kaynaklanan etkilerin belirlenmesini sağlar $[14,15]$. Böylece $\mathrm{N}$ veya $\mathrm{P}$ elementlerinin oranlarına bakılarak hangi elementin bitki için sınırlayıcı olduğu tespit edilmektedir [14]. Yaprak N:P oranı 16'dan büyük ise P elementinin sınırlayıcı olduğunu, N:P oranı 12'den küçük ise bitki gelişiminde $\mathrm{N}$ elementinin sınırlayıcı olduğunu gösterir. N:P oranı eğer 12 ile 14 arasında ise $\mathrm{N}$ ve $\mathrm{P}$ elementleri birlikte sınırlayıcıdır [3].

Dünya genelinde besin rezorbsiyonu ve toprak besinleri arasındaki ilişkileri araştıran bu ilişsinin önemli olduğunu ortaya koyan araştırmalar yapılmıştır $[2,16,17]$. Brant ve Chen, odunsu bitkiler için toprak besin maddelerinin besin rezorbsiyonu ve doğal gradyanları arasındaki ilişkileri araştırmanın zorunlu olduğunu vurgulamıştır [18]. İklim faktörlerinin de topraktan besin elementlerinin alımında önemli etkileri olduğu belirlenmiştir [18]. Bitkiler tarafindan topraktan alınabilir formda bulunan besin elementlerinin kısıtlanmasında iklim özelliklerinin yanında toprak yaşı ve ana materyalin cinsi gibi çeşitli faktörlerde etkilidir [19]. Bu faktörler bitkide besin elementlerinin korunmasında güçlü bir seçici kuvvet görevi görür [3, 20, 21]. Bu da besin bakımından zengin ve fakir bölgelerde türler arasında besin elementlerinin korumasında farklılık göstermesine neden olur $[22,23]$.

Bitkilerin çevresel faktörlere karşı vermiş olduğu tepkilerin tespitinde kullanılan diğer yaprak karakterleri arasında spesifik yaprak ağırlığı (LMA) ve alanı (SLA) en çok kullanılanlardır [24]. Spesifik yaprak alanı bitki büyüme oranı ve net fotosentez asimilasyon miktarlarıyla yakın ilişki içerisinde iken, spesifik yaprak ağırlı̆g 1 çevresel streslere karşı bitkilerin verdiği tepkilerin düzeyleri ile yakından ilişki içerindedir [25, 26]. Birçok çalışmada bu iki karakterin (SLA ve LMA) ekosistem dinamiklerini (komunitelerin ve dominant türlerin ekosistem içindeki görevleri) daha iyi açıkladığı görülmüştür [24, 27, 28]. Ayrıca yapraklardaki besin değişimi çalışmalarında spesifik yaprak alanı ve ağırlığının yaprak ömrü ile ilişsili olduğu bulunmuştur [29, 30, 31].

Rezorbsiyon miktarının belirlenmesinde kullanılan iki yöntem bulunmaktadır. Bunlar rezorbsiyon kullanım verimliliği ve rezorbsiyon kullanım yeterliliğidir [2]. Rezorbsiyon kullanım verimliliği, yaprak dökülmeden önce yaşlanmış (senesens) yapraklardan dayanıklı dokulara taşınan besin maddesi olarak tanımlanır. Distel ve arkadaşları rezorbsiyon kullanım verimliliğini besin element içeriğinin en yüksek olduğu olgun ve besin elementi içeriği en düşük olan yaşlanmış (senesens) yapraklar arasındaki farkın yüzde ifadesi olarak tanımlamıştır [32]. Bu değer hesaplanırken birim alan başına veya birim ağılık başına düşen besin elementi içeriğinin kullanılması rezorbsiyon kullanım verimliliğinin hesaplanmasında daha güvenilir sonuçların elde edilmesini sağlar. Rezorbsiyon kullanım yeterliliği ise tamamen yaşlanmış yapraklarda kalan besin elementi 
miktarıdır [2]. Ayrıca yaşlanmış yapraklardaki besin elementi içeriğinin daha düşük olmasının rezorbsiyon kullanım yeterliliğinin daha yüksek olduğu anlamına geldiğini belirtmiştir [33]. Rezorbsiyon verimliliğinden ziyade rezorbsiyon yeterliliğini kullanmanın avantajı, kısa ömürlü yaprakların besin kaybını minimize etmesinden dolayı daha güvenilir sonuçların elde edilmesidir [34].

Ailanthus altissima (Mill.) Swingle, Simaroubaceae familyasından olup, Kuzey Çin Bölgesi için yerli bir türdür [35]. Hızlı bir şekilde büyümesi ve çevresel stres faktörlerine karşı toleransının yüksek olması nedeniyle taşındığı birçok ülkede hızlıca yayılış alanlarını genişletmektedir [36]. Avrupa ve ülkemiz için istilacı tür kategorisinde olan A. altissima yayılış alanları kontrol edilmediği takdirde yerli türlerin yerini almakta ve onları ortamdan uzaklaşmasına neden olmaktadır [37]. Fakat türün hızlı büyüme özelliğinden dolayı birçok bölgede peyzaj çalışmalarında kullanılmaktadır [38]. Yine tür hakkında yapılan çalışmalar incelendiğinde düşük besin konsantrasyonlu topraklarda iyi gelişebilmesinin yanında [39] yüksek N içeriğine sahip ve su kıtlı̆̆ının olduğu alanların türün gelişimini olumsuz etkilemediği bulunmuştur [40]. Li ve arkadaşları özellikle yüksek N içerikli toprakların türün gelişimini hızlandırdığını belirlemiş̧lerdir [40].

$\mathrm{Bu}$ çalışmada ise türün ortaya konmayan $\mathrm{N}$ ve $\mathrm{P}$ elementleri için rezorbsiyon miktarları ile yaprak $\mathrm{N}: \mathrm{P}$ oranları hesaplanmış ve bazı toprak özellikleriyle (toprak N (\%) içeriği, toprak P (\%) içeriği, toprak pH'sı ve toprak elektriksel iletkenliği) olan ilişkileri açıklanmaya çalışılmıştır. Bunun için (i) hangi besin elementinin yapraklardan daha çok geri alındığı? (ii) hangi besin elementinin tür için sınırlayıcı etkiye sahip olduğu? (iii) toprak özellikleri ile rezorbsiyon miktarları arasında nasıl bir ilişkinin olduğu? (iv) son olarak türle ilgili yapılan çalışmalar incelendiğinde düşük $\mathrm{N}$ içerikli toprakların türün gelişimini etkilemediği ortaya konduğuna göre $\mathrm{N}$ içeriğinin az olduğu alanlarda rezorbsiyon yeteneğinin yüksek, N içeriği yüksek alanlarda ise rezorbsiyon yeteneğinin daha az olmalı? sorularına cevaplar aranmıştır. Böylece ortaya çıkan sonuçların özellikle türün istilacılık potansiyeline karşı alınabilecek önlemlere katkılar sunması beklenmektedir.

\section{MATERYAL METOT}

Araştırma alanı Sakarya ili Hendek ilçesinde yer alan tahribatın yoğun olduğu Süleymaniye ormanlarıdır (Şekil 1). Fraxinus angustifolia subsp. oxycarpa (Willd.) Franco \& Rocha Afonso türünün hâkim olduğu çalışma alanında, ormanı karakterize etmeyen Trifolium repens L., Euphorbia palustris L., Ailanthus altissima (Mill.) Swingle gibi birçok türün olduğu tespit edilmiştir. Alanın yıllık sıcaklık ortalaması $14.3^{\circ} \mathrm{C}$, yıllık yağış miktarı $773.7 \mathrm{~mm}$, yıllık ortalama bağı $1 \mathrm{nem} \% 72$ (vejetasyon aylarında ortalama \% 70.6) olarak hesaplanmıştır. Kış aylarında ise sıcaklık $-12.5^{\circ} \mathrm{C}$ ye düşebilmektedir.

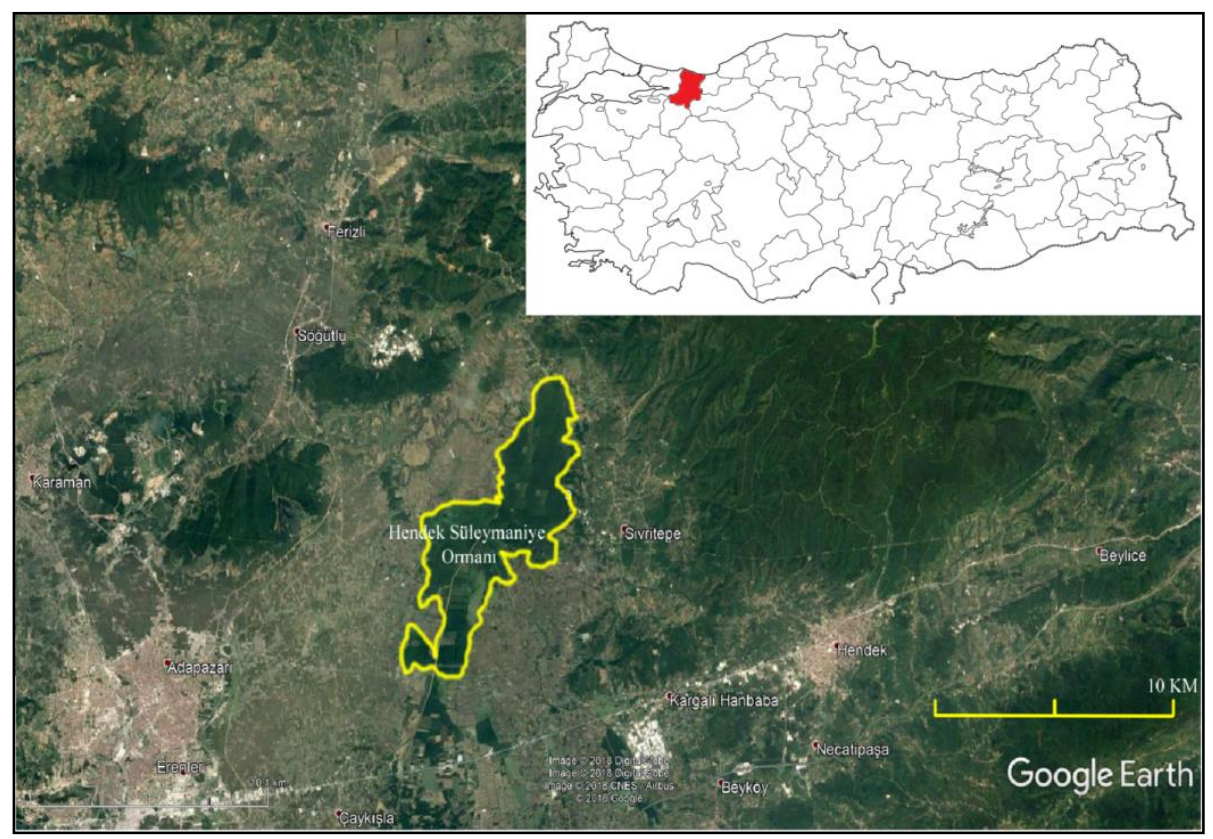




\section{Şekil 1. Çalışma alanı}

Çalışma alanı vejetasyon ve çevresel özellikler (topoğrafya vb.) bakımından hemen hemen homojen olup, tür içinde meydana gelebilecek mikro-çevresel varyasyonu önlemek amacıyla ormanın genelini temsil edecek şekilde 3 alan belirlenmiştir. Belirlenen alanlarda birbirinden en az $2.5 \mathrm{~m}$ uzaklıkta olan 3 birey belirlenmiştir [41]. Belirlenen alanlardan vejetasyon dönemi (Nisan - Kasım 2017) boyunca eşit büyüklükte, zarar görmemiş ve aynı sürgünden en az 10 adet yaprak toplanmıştır. Ayrıca belirlenen alanlardan toprak burgusu yardımıyla $0-50 \mathrm{~cm}$ derinlikten profil boyunca yeterli miktarda toprak örneği vejetasyon dönemi boyunca her ay alınmıştır.

Yaprak örnekleri alan ölçümlerinden önce preslenmiş ve düz hale getirilmiştir. Düzleştirilen yaprak örneklerinin sapları kesilerek "Leaf Area Measurement Software" programı ile alanları ölçülmüştür. Alan ölçümünden sonra yaprak kuru ağırlıklarının hesaplanması için yaprak örnekleri $70^{\circ} \mathrm{C}^{\prime}$ de sabit ağırlığa ulaşıncaya kadar etüvde kurutulmuştur. Elde edilen veriler ile spesifik yaprak alanı (SLA) ve spesifik yaprak ağırlığı (LMA) aşağıdaki formüllere göre hesaplanmıştır.

$$
\begin{aligned}
& S L A\left(\mathrm{~mm}^{2} / \mathrm{mg}\right)=\text { yaprak alanı/kuru yaprak ăg } \iota r l \mathrm{~g} \iota \\
& \text { LMA }\left(\mathrm{mg} / \mathrm{mm}^{2}\right)=\text { kuru yaprak ăğrlı̆̆ } / \text { yaprak alanı }
\end{aligned}
$$

SLA ve LMA değerleri ölçüldükten sonra her bir alandan toplanan yaprak örnekleri öğütülerek 3 farklı örneklik alan için yaprak havuzları oluşturulur [42].

Yaprak ve toprak örneklerindeki toplam N miktarlarının belirlenmesi için öğ̈̈tülmüş yaprak örnekleri ile oda sıcaklığında kurutulan ve $2 \mathrm{~mm}$ 'lik elekten geçirilerek analize hazır hale getirilen toprak örneklerinden birer gr alınarak Kjeldahl yöntemi uygulanmıştır. Kjeldahl yöntemi ile $\mathrm{H}_{2} \mathrm{SO}_{4}$ ile yaş yakılan toprak örneğindeki organik azotu $\mathrm{NH}_{4}+\mathrm{N}$ şekline dönüştürmek ve alkali ortamda yapılan distilasyon ile açığa çıkan $\mathrm{NH}_{3}$ miktarında toprağın total $\mathrm{N}$ içeriğini belirleme esasına dayanmaktadır [43, 44, 45].

Yaprak örneklerinde uygulanan fosfor analizi yönteminin prensibi yaş yakma yöntemi ile yakılmış bitki örneğinin Barton çözeltisi ile renklendirildikten sonra oluşan rengin indensitesinin standart seriye karşıllk spektrofotometrede belirlenmesi esasına dayanmaktadır [46]. Baron çözeltisi şu şekilde hazırlanır: 25 gr saf amonyum molibdat $\left(\left(\mathrm{NH}_{4}\right)_{2} \mathrm{Mo}_{7} \mathrm{O}_{24} \cdot 4 \mathrm{H}_{2} \mathrm{O}\right) 400 \mathrm{ml}$ 'lik deiyonize suda çözülür. Çözünmeyi kolaylaştırmak için $50^{\circ}$ 'ye kadar 1sitılır ve süzülür. 1.25 gr amonyum meta vanadat $\left(\mathrm{NH}_{4} \mathrm{VO}_{3}\right) 1000$ ml'lik mezür içerisinde $300 \mathrm{ml}$ kaynar suda çözülür. Oda sıcaklığına kadar soğutulur ve üzerine $250 \mathrm{ml}$ konsantre nitrik asit $\left(\mathrm{HNO}_{3}\right)$ eklenir. Tekrar oda sıcaklığına kadar soğutulan çözeltiye daha önce hazırlanmış olan amonyum molibdat ilave edilir.

Toprak örneklerinde alınabilir fosfor tayini, toprağın asidik ve bazik durumuna göre değişmektedir. Asidik topraklarda alınabilir fosfor tayini, Bray ve Kurtz yöntemine göre belirlenir [47]. Bu yöntemde ekstrakt çözeltisine $\left(0,03\right.$ norrmalite $\mathrm{NH}_{4} \mathrm{~F}+0,025$ normalite $\left.\mathrm{HCl}\right)$ geçen fosfor, molibdofosforik mavi renk yöntemine göre kolorimetrik olarak belirlenmektedir.

1/2.5 oranında toprak-saf su karışımı 1 gece bekletilmek suretiyle pH metresinde ölçülmüştür [48, 49, 50]. Elektriksel iletkenliğin belirlenmesi için toprak örnekleri $1 / 5$ oranında saf su ile 1slatılıp mekanik karıştırıcıda 1 saat karıştırıldıktan sonra elektriksel iletkenlik aleti ile ölçüm yapılmıştır [51, 52].

$\mathrm{N}$ ve P rezorbsiyon verimliliği (NRE ve PRE) aşağıdaki formüllere göre hesaplanmıştır. Yaprakların en olgun olduğu aydaki besin elementi içeriğinden, senesens dönemindeki minimum besin elementi içeriği çıkarılarak yaprakların en olgun olduğu aydaki besin elementi içeriğine bölünür ve 100 ile çarpılır [33]. Rezorbsiyon hesaplamalarında; olgun ay yaprak besin elementi içeriğinin en yüksek olduğu, senesens ay ise yaprak besin elementi içeriğinin en düşük olduğu ayı ifade eder.

$$
N R E=\left(1-\frac{\text { Nsenesens }}{\text { Nolgun }}\right) \times 100
$$




$$
\text { PRE }=\left(1-\frac{\text { Psenesens }}{\text { Polgun }}\right) \times 100
$$

Vergutz ve arkadaşları senesens sırasında yaprak alanı ve ağırlığındaki değişimlerden dolayı hataları en aza indirmek için düzeltme faktörü kullanmışlardır [17]. Bu kütle kaybı düzeltme faktörü (MLCF), senesens yapraklarının kuru ağırlığının en yüksek besin içeriğine sahip aydaki yeşil yapraklara oranı olarak hesaplanmıştır $[17,53]$.

$$
M L C F=\frac{\text { senesens yaprakların kuru ağırlığ } l}{\text { olgun yaprakların kuru ă̆ırlığ } \iota}
$$

$\mathrm{Bu}$ çalışmada ağırlık yönünden $\mathrm{N}$ ve $\mathrm{P}$ rezorbsiyon verimliliği ayrıca kütle kaybı düzeltme faktörü (MLCF) kullanılarak hesaplanmıştır [17].

$$
\begin{aligned}
& \text { NRE }=\left(1-\frac{\text { Nsenesens }}{\text { Nolgun }} * M L C F\right) \times 100 \\
& P R E=\left(1-\frac{\text { Psenesens }}{\text { Polgun }} * M L C F\right) \times 100
\end{aligned}
$$

$\mathrm{N}$ ve $\mathrm{P}$ rezorbsiyon kullanım yeterliliği (NRP ve PRP) senesens yapraklarındaki en yüksek besin elementi içeriği olarak ifade edilir [33].

Çalışmada tüm verilerin istatistiksel analizleri SPSS V.25 paket programı kullanılarak yapılmıştır [54]. Çalışma için belirlenen 3 farklı alan vejetasyon ve çevresel özellikler (topoğrafya vb.) bakımından benzer olmasına rağmen kimyasal özellikleri bakımından farklı olup olmadığını belirlemek için vejetasyon dönemi toplanan örneklerde ANOVA istatistiksel yöntemi kullanılmıştır. Toprak N ve P içeriklerinin en yüksek en düşük olduğu aylara göre belirlenen senesens ve olgun dönemdeki yaprak karakterleri (SLA ve LMA), N ve P içerikleri, N:P oranları ve rezorbsiyon düzeylerinin alanlar arasındaki farklılığı belirlemek içinde ANOVA istatistiksel yöntemi kullanılmıştır. Ayrıca hem toprak özellikleri hem de yaprak özelliklerinde farklılığın nereden kaynaklandığını belirlemek için Tukey HSD testi kullanılmıştır. Son olarak rezorbsiyon değerleri ile toprak özellikleri arasındaki ilişkinin yönü ve önemi Pearson korelasyon katsayısı kullanılarak bulunmuştur.

\section{III.BULGULAR}

A. altissima'ya ait olgun dönemindeki SLA ve LMA değerleri incelendiğinde; olgun dönemdeki SLA değerinin 40.52 ile $42.79 \mathrm{~mm}^{2} / \mathrm{mg}$ arasında değişirken; olgun LMA değerleri ise 0.024 ile $0.026 \mathrm{mg} / \mathrm{mm}^{2}$ arasında değiştiği bulunmuştur. ANOVA istatistiksel yöntemine göre olgun dönemdeki SLA ve LMA değerleri örneklemler arasında $\mathrm{p}<0.05$ düzeyinde istatistikse olarak farklı bulunmuştur. Tukey HSD testine göre de her bir örneklem ayrı bir grup oluşturmuştur (Şekil 2).

Senesens dönemindeki SLA ve LMA değerleri incelendiğinde; senesens dönemdeki SLA değerinin 31.28 ile $34.42 \mathrm{~mm}^{2} / \mathrm{mg}$ arasında değişirken; senesens LMA değerleri ise 0.032 ile $0.035 \mathrm{mg} / \mathrm{mm}^{2}$ arasında değiştiği bulunmuştur. ANOVA istatistiksel yöntemine göre senesens dönemdeki SLA ve LMA değerleri örneklemler arasında $\mathrm{p}<0.05$ düzeyinde istatistiksel olarak farklı bulunmuştur. Tukey HSD testine göre örneklemeler 2 ayrı grup oluşturmuştur (Şekil 2). 

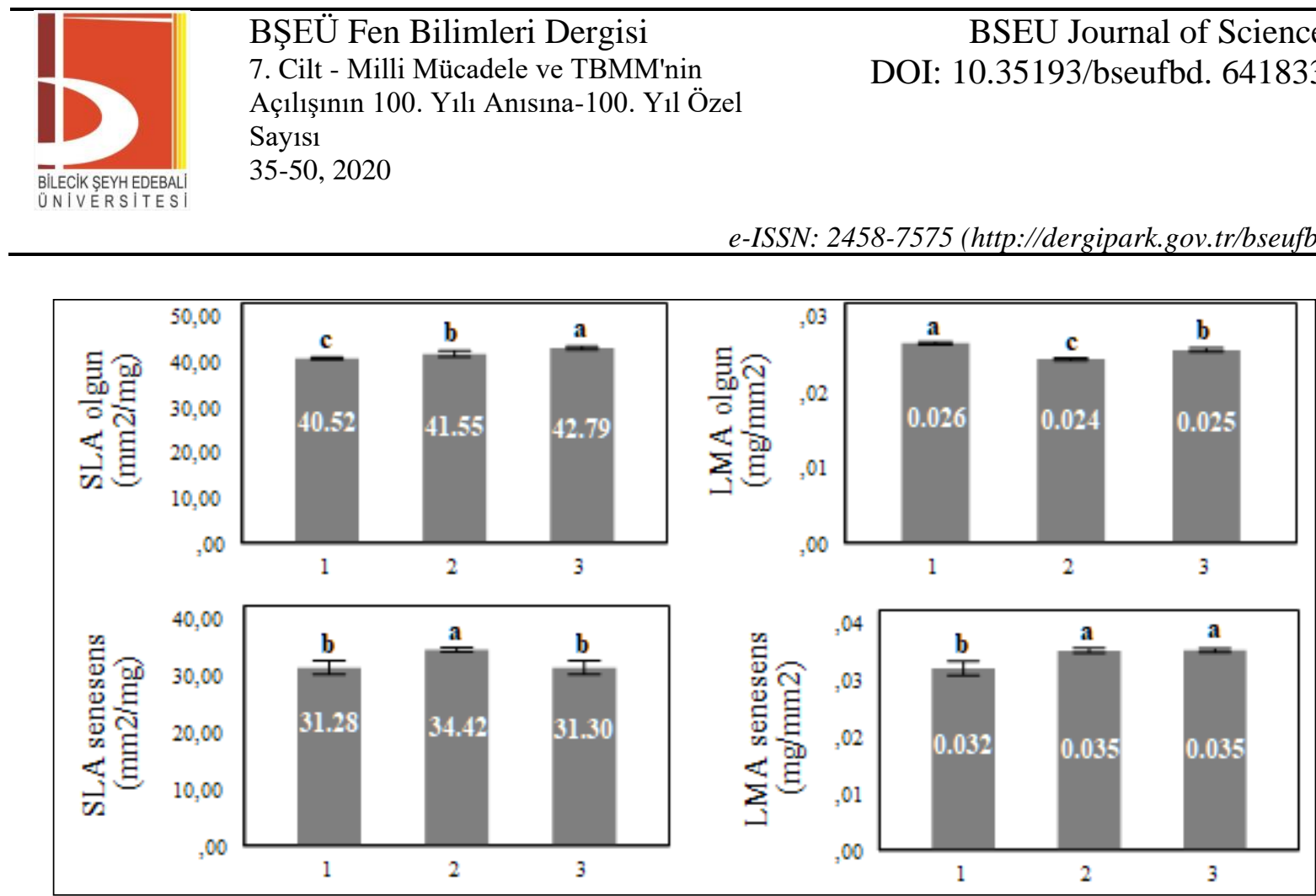

Şekil 2. A. altissima'ya ait SLA ve LMA değerlerinin alanlar arasındaki değişimi (Barlar üzerindeki harfler $\mathrm{p}<0.05$ düzeyinde Tukey testi sonuçlarını ifade eder.).

Türe ait $\mathrm{N}$ ve $\mathrm{P}$ içerikleri incelendiğinde; olgun dönemdeki $\mathrm{N}$ içeriği 46.87-49.53 mg/g arasında değişirken, $\mathrm{P}$ içeriği ise 2.94-3.20 mg/g arasında değişmektedir. İstatistiksel olarak olgun $\mathrm{N}$ ve $\mathrm{P}$ içerikleri örneklemler arasında $\mathrm{p}<0.05$ düzeyinde farklı bulunmuştur. Tukey HSD testine göre olgun $\mathrm{N}$ içerikleri 3 farklı grup oluştururken, olgun P içeriği ise iki farklı grup oluşturmuştur (Şekil 3).

Senesens dönemindeki yaprakların $\mathrm{N}$ ve $\mathrm{P}$ içerikleri incelendiğinde; $\mathrm{N}$ içeriği 12.56-14.06 mg/g arasında değişirken, P içeriği ise 1.63-1.83 arasında değişmektedir. Her iki element örneklemler arasında istatistiksel olarak $\mathrm{p}<0.05$ düzeyinde farklı bulunmuştur. Ayrıca her iki element için her üç örneklem Tukey HSD testine göre ayrı grup oluşturduğu bulunuştur (Şekil 3).

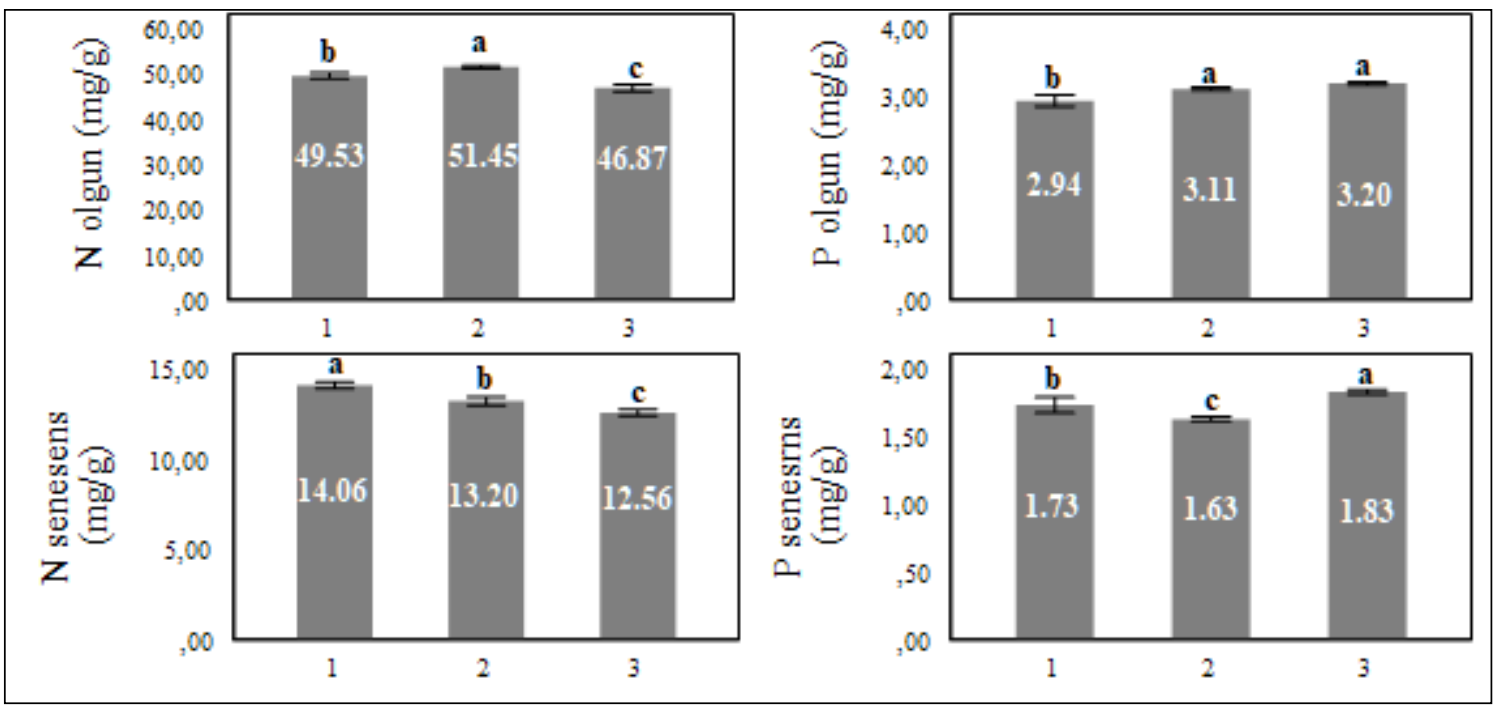

Şekil 3. A. altissima'ya ait yaprak N ve P değerlerinin alanlar arasındaki değişimi (Barlar üzerindeki harfler $\mathrm{p}<0.05$ düzeyinde Tukey testi sonuçlarını ifade eder.).

Türe ait N:P oranlarının örneklemler arasındaki değişimine bakıldığında; olgun dönemde N:P oranının 14.69 ile 16.87 arasında değiştiği, senesens dönemindeki N:P oranının 6.88 ile 8.13 arasında değiştiği 
bulunmuştur. İstatistiksel olarak olgun ve senesens dönemdeki $\mathrm{N}: \mathrm{P}$ oranlarının örneklem arasında $\mathrm{p}<0.05$ düzeyinde farklı olduğu bulunmuştur. Ayrıca her iki dönemde N:P oranının örneklemler arasında 2 grup oluşturduğu Tukey HSD testine göre bulunmuştur (Şekil 4).

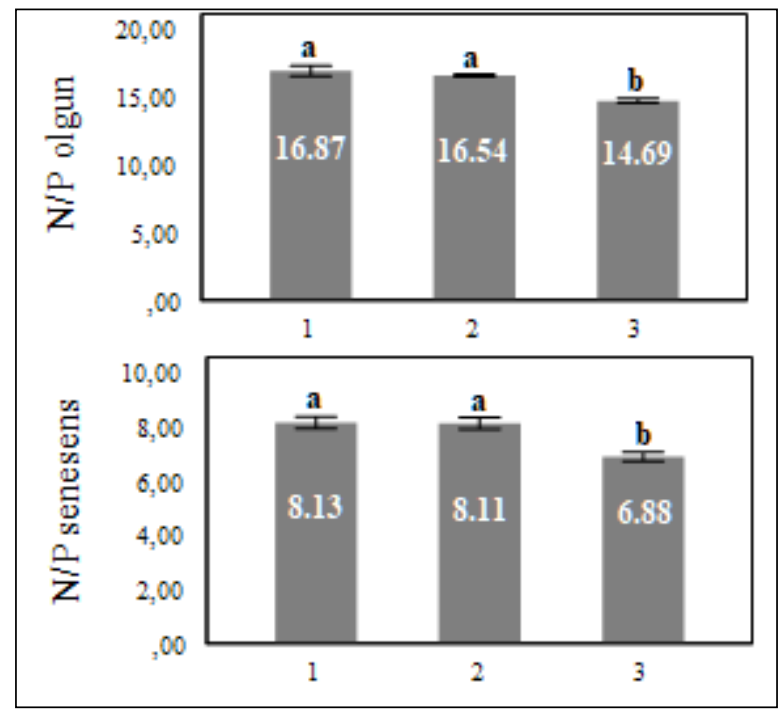

Șekil 4. A. altissima'ya ait yaprak N/P oranlarının alanlar arasındaki değişimi (Barlar üzerindeki harfler p $<0.05$ düzeyinde Tukey testi sonuçlarını ifade eder.).

Türün $\mathrm{N}$ ve $\mathrm{P}$ rezorbsiyon verimlilik değerlerine bakıldığında; NRE değerlerinin \% arasında, PRE değerlerinin ise \%41.08-47.70 arasında değiştiği hesaplanmıştır. Kütle kaybı düzeltme faktörü (MLCF) ile hesaplanan rezorbsiyon verimliliklerine bakıldığında NRE için \%73.39-75.97 arasında değiştiği, PRE için ise \%44.79-50.99 arasında değiştiği bulunmuştur. İstatistik olarak NRE ve NRE (mlcf) değerlerinde $\mathrm{p}<0.05$ düzeyinde önemli farklılık bulunmuştur. Ayrıca her iki değişken Tukey HSD testine göre 3 grup oluşturmuştur. PRE ve PRE (mlcf) değerleri de örneklemeler arasında $\mathrm{p}<0.05$ düzeyinde önemli farklılık bulunmuştur. Fakat Tukey HSD testine göre her iki değişken 2 grup oluşturmuştur (Şekil 5).

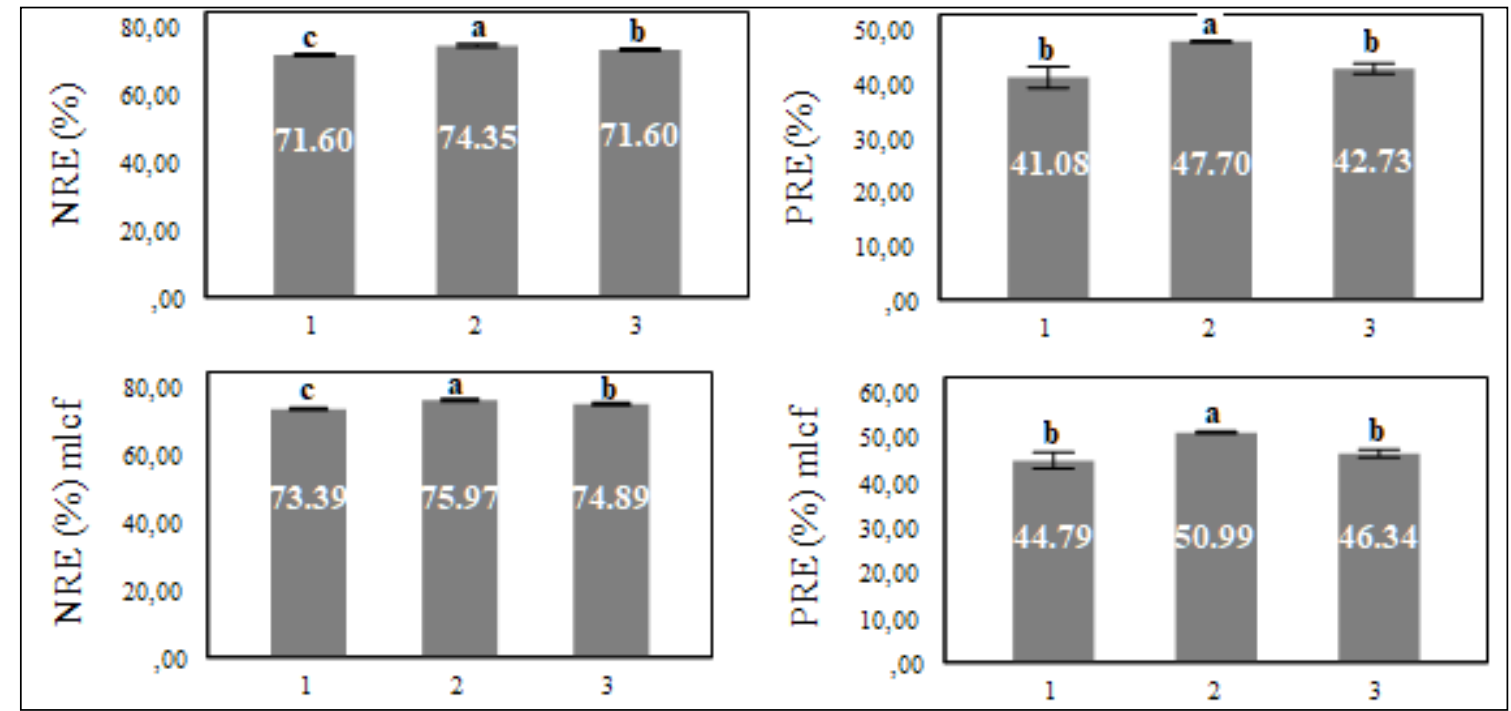

Şekil 5. A. altissima'ya ait yaprak N ve P rezorbsiyon verimlilik (NRE, PRE) değerlerinin alanlar arasındaki değişimi (Barlar üzerindeki harfler $\mathrm{p}<0.05$ düzeyinde Tukey testi sonuçlarını ifade eder.). 


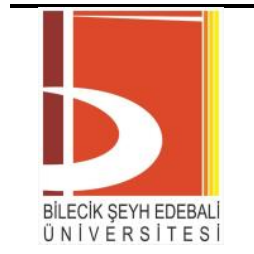

BŞEÜ Fen Bilimleri Dergisi

BSEU Journal of Science

7. Cilt - Milli Mücadele ve TBMM'nin

Açılışının 100. Yı1lı Anısına-100. Yıl Özel

DOI: $10.35193 /$ bseufbd. 641833

Sayis1

$35-50,2020$

e-ISSN: 2458-7575 (http://dergipark.gov.tr/bseufbd)

Türün N ve P rezorbsiyon yeterlilik değerlerine bakıldığında; NRP değerlerinin 12.56-14.06 mg/g arasında değişirken; PRP ise 1.63-1.83 mg/g olarak hesaplanmıştır. İstatistiksel yönden değerlendirildiğinde NRP ve PRP örneklemeler arasında $\mathrm{p}<0.05$ düzeyinde önemli farklılık bulunmuştur. Tukey HSD testine göre ise NRP ve PRP her iki değişken 2 grup oluşturmuştur (Şekil 5). Ayrıca Tukey HSD testine göre 3 grup bulunmuştur (Şekil 5).

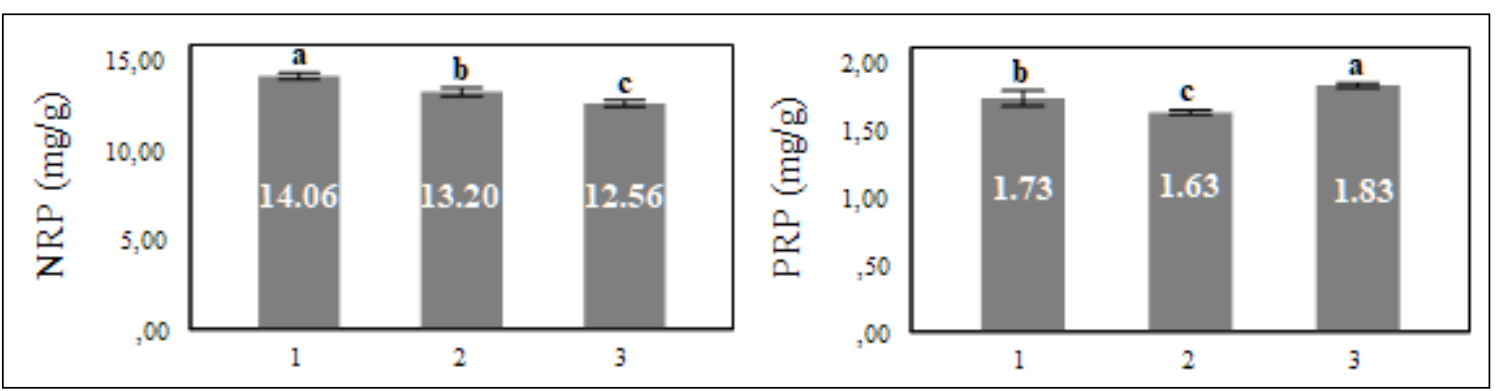

Şekil 5. A. altissima'ya ait yaprak N ve P rezorbsiyon yeterlilik değerlerinin (NRP, PRP) alanlar arasındaki değişimi (Barlar üzerindeki harfler $\mathrm{p}<0.05$ düzeyinde Tukey testi sonuçlarını ifade eder.).

Toprak analizleri incelendiğinde, toplam $\mathrm{N}$ içeriği ve alınabilir P içeriği örnekleme yapılan alanlar arasında $\mathrm{p}<0.05$ düzeyinde farklı bulunmuştur. Toprak $\mathrm{N}$ içeriği \%1.03-1.39 aralığında değişirken, toprak $\mathrm{P}$ içeriği ise \%0.013-0.018 aralığında değişmektedir. Toprak pH değerleri 6.71-6.84 aralığında, toprak EC değeri ise 0.096-0.104 (mS) aralı̆̆ında değişmektedir. $\mathrm{pH}$ değerlerinin örnekleme yapılan alanlar arasında $\mathrm{p}<0.05$ düzeyinde istatistiksel olarak farklı bulunmasına rağmen toprak elektriksel iletkenlik değerlerinde böyle bir farklılık bulunmamıştır. Ayrıca her bir toprak değişkeni için Tukey HSD testleri yapılmış olup, elektriksel iletkenlik hariç diğer değişkenlerin iki grup meydana getirdiği bulunmuştur (Şekil 6).

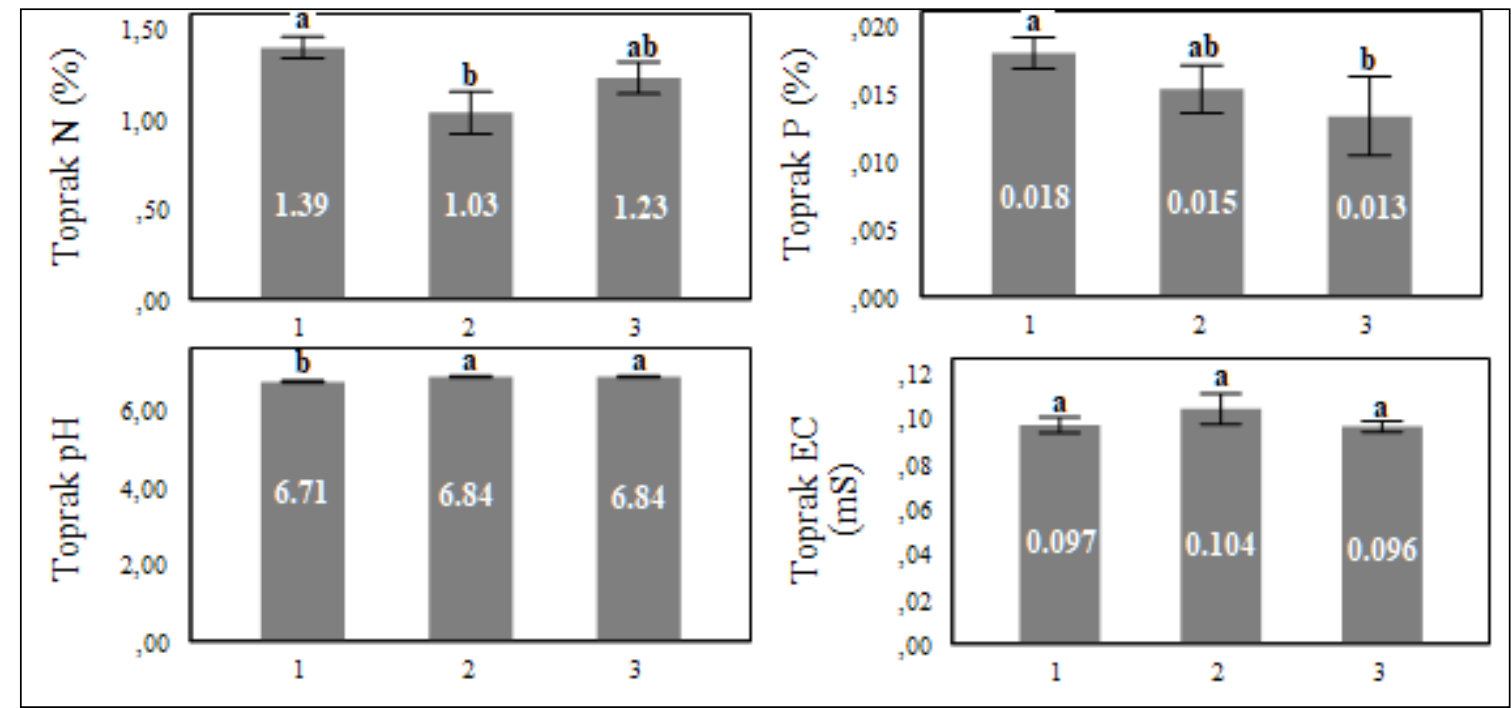

Şekil 6. Toprak özelliklerinin alanlar arasındaki değişimi (Barlar üzerindeki harfler $\mathrm{p}<0.05$ düzeyinde Tukey testi sonuçlarını ifade eder.).

Son olarak A. altissima'nın rezorbsiyon değerleri ile toprak özellikleri arasındaki ilișkinin yönü ve düzeyinin belirlenmesi amacıyla yapılan korelasyon testi incelendiğinde; NRE ve NRE (mlcf) değerlerinin toprak $\mathrm{N}$ içeriği ile negatif yönde, toprak $\mathrm{pH}$ değerleri ile pozitif yönde ilişki olduğu bulunmuştur. Bu ilişkilerin düzeyi toprak $\mathrm{N}$ içeriği ve toprak $\mathrm{pH}$ 'sı ile $\mathrm{p}<0.01$ seviyesinde olduğu tespit edilmiştir. PRE ve PRE (mlcf) değerlerine bakıldığında; toprak $N$ içeriği ile negatif yönde ve $p<0.01$ düzeyinde ilişki bulunmuştur. Toprak $p H$ ve EC değerleri ile pozitif yönde ve $\mathrm{p}<0.05$ düzeyinde ilişki bulunmuştur. Son olarak rezorbsiyon yeterliliğine bakıldığında; NRP ile toprak $\mathrm{P}$ içeriği arasında pozitif yönde ve $\mathrm{p}<0.05$ düzeyinde, toprak $\mathrm{pH}$ 'sı ile negatif 


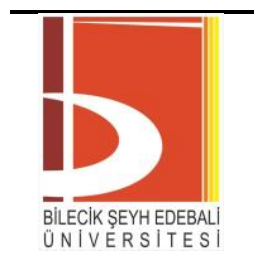

BŞEÜ Fen Bilimleri Dergisi

7. Cilt - Milli Mücadele ve TBMM'nin

Açılışının 100. Yılı Anısına-100. Yıl Özel

Say1s1

$35-50,2020$

e-ISSN: 2458-7575 (http://dergipark.gov.tr/bseufbd)

yönde ve $p<0.01$ düzeyinde ilişki bulunmuştur. PRP ise sadece toprak elektriksel iletkenlik ile negatif yönde ve $\mathrm{p}<0.05$ düzeyinde ilişki bulunmuştur.

Tablo 1. A. altissima'ya ait yaprak $\mathrm{N}$ ve $\mathrm{P}$ rezorbsiyon değerleri ile toprak özellikleri arasındaki ilişki.

\begin{tabular}{|c|c|c|c|c|}
\hline \multicolumn{5}{|c|}{ Korelasyon } \\
\hline & Toprak N (\%) & Toprak P (\%) & Toprak_pH & Toprak EC $(\mathrm{mS})$ \\
\hline NRE (\%) & $-0.854^{* * *}$ & -0.493 & $0.882^{* *}$ & 0.515 \\
\hline $\mathrm{NRE}_{\text {mlcf }}(\%)$ & $-0.857^{* *}$ & -0.493 & $0.891^{* *}$ & 0.515 \\
\hline NRP (mg/g) & 0.480 & $0.695^{*}$ & $-0.879^{* *}$ & 0.101 \\
\hline PRE (\%) & $-0.820^{* *}$ & -0.343 & $0.613^{*}$ & $0.722^{*}$ \\
\hline $\operatorname{PRE}_{\text {mlef }}(\%)$ & $-0.823^{* *}$ & -0.343 & $0.627^{*}$ & $0.731^{*}$ \\
\hline PRP (mg/g) & 0.510 & -0.204 & -0.008 & $-0.613^{*}$ \\
\hline \multicolumn{5}{|c|}{ *. 0.05 düzeyinde önemli korelasyon } \\
\hline **. 0.01 düzey & orelasyon & & & \\
\hline
\end{tabular}

\section{TARTIŞMA}

A. altissima ekolojik yönden hem firsatçı hem de konservatif strateji özelliklerini barındıran istilacı bir türdür [36]. Fırsatçı karakteri çok fazla ölü örtü üretmesi [55] ve yaprak azot içeriğinin yüksek olmasından, konservatif karakteri ise azot rezorbsiyon oranının yüksek olmasındandır. Birçok farklı ekosistemde A. altissima ile yapılan çalışmalarda, türün ölü örtüsünün yerli türlerinkine göre daha hızlı ayrışması, azotun topraktan alınmasında ve korunmasında daha verimli olduğunu ortaya koymuştur $[56,57,58]$.

$\mathrm{Bu}$ çalşşmada türe ait azot rezorbsiyon değerleri incelendiğinde; \%70'in üzerinde olduğu tespit edilmiştir. Kütle kaybı düzeltme faktörü ile hesaplanan NRE değerleri \%73.39-75.97 arasında, düzeltme faktörü kullanılmadan hesaplanan değer ise \%71.60-74.35 arasındadır. Yaprak döken türler için azotun yapraklardan geri alınma oranının \%80'e kadar çıkabildiği Aerts ve Chapin tarafından belirtilmiştir [3]. Aerts, $\mathrm{N}$ için verimlilik değerini $\% 52$ olarak tespit etmiş ve bu değerin üzerinde azotu yapraklarından geri alabilen türlerin rezorbsiyon yönünden verimli olduğunu önermiştir [2]. González-Muñoz ve arkadaşları araştırma alanına benzer bir ekosistemde yaptı̆̆ı çalışmada istilacı türelere ait kütle kaybı düzeltme faktörünü kullanarak hesapladığı NRE değerlerinin azot fikse etmeyen A. altissima için \%78, Ulmus pumila L. için \%71, azot fikse eden Robinia pseudoacacia L. için \%37 bulmuştur [55]. A. altissima azot fikse etmeyen bir tür olarak González-Muñoz ve ark. [50] değerleri ile benzer bulunmuştur. Ayıca $\mathrm{N}$ fikse edebilen türlerin $\mathrm{N}$ rezorbsiyon oranlarının düşük olduğu birçok çalışma ile ortaya konmuştur [59, 60, 61].

Türe ait fosfor rezorbsiyon değerlerine bakıldığında; kütle kaybı düzeltme faktörü ile hesaplanan değerler \%44.79-50.99 arasında iken düzeltme faktörü kullanılmadan hesaplanan değer ise \%41.08-47.70 arasında değişmektedir. Aerts, fosfor rezorbsiyon verimlilik değeri olarak \% 50 oranını belirlemiștir [2]. Bu değere göre; A. altissima bu sınır değere ulaşsa da çoğu bireyin fosfor rezorbsiyon verimliliği (PRE) \%50'nin altında bulunmuştur. Türün daha önce hesaplanan fosfor rezorbsiyon değeri olmamasına rağmen, benzer ekosistemlerde bulunan diğer yaprak döken türlerle karşılaştırıldığında daha düşük rezorbsiyon verimliliğine sahip olduğu görülmüştür. Genel olarak fosfor rezorbsiyon değerleri yaprak döken türler için \%29.1-79.7 arasında değişirken [62,63]; Sohrt ve arkadaşları 1lıman ormanlarda yer alan türlerde yaptığı çalışmada ortalama PRE değerini \%48 olarak hesaplamıştır [64]. Dünya genelinde yaprak döken türlere ait PRE değerlerine bakıldığında; bu çalışmada ortalamanın üzerinde rezorbsiyon verimliliğine sahip olduğu bulunmuştur.

Azot ve fosfor rezorbsiyon yeterlilik değerlerine bakıldığında; NRP değerlerinin 12.56-14.06 mg/g arasında, PRP değerinin ise $1.63-1.83 \mathrm{mg} / \mathrm{g}$ arasında değiştiği belirlenmiştir. Killingbeck, $\mathrm{N}$ tespit etmeyen türler için N rezorbsiyon yeterlilik oranını \%0.87 olarak belirlerken [33]; Short ve arkadaşları ise 1lıman ormanlarda yaprak döken ağaçların ortalama NRP değerini $10.24 \mathrm{mg} / \mathrm{g}$ olarak hesaplamıştır [59]. A. altissima için belirlenen senesens yaprakların $\mathrm{N}$ içeriği ise $12 \mathrm{mg} / \mathrm{g}$ olarak bulunmuştur [50]. Benzer ekosistemlerde yapılan çalışmalar 
incelendiğinde; PRP değerlerinin 0.80-1.32 mg/g arasında değiştiği görülmektedir [57, 58, 56]. Son yıllarda yapılan ılıman ormanlarda yaprak döken ağaçlar için belirlenen ortalama PRP değerinin $(0.77 \mathrm{mg} / \mathrm{g})$ üzerinde olduğu görülmektedir [59]. Türe ait P rezorbsiyon çalışmaları olmadığı için, karşılaştırmalar ılıman ormanlardaki yaprak döken ağaçlar ile yapılmıştır.

Genel olarak A. altissima'ya ait rezorbsiyon değerleri incelendiğinde, özellikle yapraklardan azot alımında daha başarılı olduğu görülmektedir.

Türe ait stratejilerin yorumlanmasında kullanılan önemli parametreler arasında spesifik yaprak alanı ve ağırlığı (SLA ve LMA) ile yaprak N:P oranları gelmektedir. Olgun dönemdeki SLA değerlerinin 40.52 ile 42.79 $\mathrm{mm}^{2} / \mathrm{mg}$, LMA değerlerinin ise 0.024 ile $0.026 \mathrm{mg} / \mathrm{mm}^{2}$ arasında değiştiği belirlenmiştir. Senesens dönemdeki SLA değerinin 31.28 ile $34.42 \mathrm{~mm}^{2} / \mathrm{mg}$, LMA değerlerinin ise 0.032 ile $0.035 \mathrm{mg} / \mathrm{mm}^{2}$ arasında değiştiği bulunmuştur. Türe ait önceki çalışmalar incelendiğinde LMA $5.04 \mathrm{mg} / \mathrm{cm}^{2}$ ve $7.66 \mathrm{mg} / \mathrm{cm}^{2}$ olarak tespit edilmiştir [55, 65]. Bu değerler olgun döneme ait olup mevcut çalışmadaki olgun döneme ait LMA değerlerine göre daha yüksek olduğu bulunmuştur. Bunun nedeni olarak çalışma alanındaki A. altissima'nın tepe tacını oluşturmaması veya tepe tacını oluşturan Fraxinus angustifolia subsp. oxycarpa topluluklarının altında kalmasından kaynaklandığı söylenebilir. Çünkü genel olarak orman ekosistemlerinde LMA vejetasyonun üst katlarından alt katlarına doğru azaldığı tespit edilmiştir [66]. Ayrıca toprağın suyla doygun olduğu alanlarda LMA değerlerinin daha az olduğu çeşitli çalışmalarda tespit edilmiştir [67, 68, 69, 70]. Bu durumda çalışma alanın suyla doygun topraklara sahip olduğu düşünüldüğünde bu farklılığı açıklamakladır.

Türün yaprak N:P oranları incelendiğinde; olgun dönemde 14.69 ile 16.87 arasında, senesens döneminde ise 6.88 ile 8.13 arasında değiştiği bulunmuştur. Bu sonuçlar olgun dönemde A. altissima için $\mathrm{P}$ elementinin sınırlayıcı, senesens döneminde ise $\mathrm{N}$ elementinin sınırlayıcı olduğunu gösterir. Bu durum özellikle senesens dönemindeki yaprak $\mathrm{N}$ içeriğinin düşük olduğunu ve türün daha çok azotu dayanıklı dokularına transfer ederek korumacı stratejisini ortaya çıkarır. Ayrıca olgun dönemde P elementinin sınırlayıcı olması tür için olumsuz koşullar meydana getirmez. Çünkü yapılan çalışmalarda A. altissima $\mathrm{P}$ elementi yönünden zayıf topraklarda bile iyi gelişebildiği ortaya konmuştur [71]. Sonuç olarak, hem firsatçı hem de korumacı stratejiler sergileyen istilacı A. altissima türü çalışma alanında hem olgun dönemde hem de senesens dönemde diğer türlere göre ekolojik üstünlüğe sahiptir.

Son olarak türe ait rezorbsiyon değerleri ile çalışma alanının toprak özellikleri incelendiğinde; NRE ve $\mathrm{NRE}_{\text {mlcf }}$ değerlerinin toprak $\mathrm{N}$ içeriği ile negatif yönde, toprak $\mathrm{pH}$ değerleri ile pozitif yönde ilişki olduğu bulunmuştur. Çalışma alanının N toprak içeriği yüksek olmasından dolayı, A. altissima'nın NRE değerlerinin düşük olması beklenirdi. Fakat sonuçlara göre A. altissima'ya ait NRE değeri yüksek çıkmıştır. Bu durum iki şekilde açıklanabilir; birincisi A. altissima'nın fırsatçı ve korumacı stratejiler sergilemesinden dolayı [55], ikincisi ise çalışma alanının suya doygun olması nedeniyle azotun alınabilir formda olmamasıdır [72]. Bazı Akdeniz adalarında yapılan çalışmalarda, A. altissima varlığının bulunduğu alanlardaki azot varlığını ve pH değerini arttırdığı, bununla beraber alanın tür zenginliğini azalttığı belirlenmiştir [73]. Yine benzer sonuçlar, Hayes ve arkadaşları tarafından Avustralya' da istilacı türlerle ilgili yapılan çalışmada bulunmuştur [74].

Fosfor rezorbsiyon verimliği (PRE ve $\mathrm{PRE}_{\mathrm{mlcf}}$ ) incelendiğinde; toprak $\mathrm{N}$ içeriği ile negatif, toprak pH ve EC değerleri ile pozitif ilişki bulunmuştur. Yapılan çalışmalarda fosfor rezorbsiyon verimliğinin topraklardaki $\mathrm{P}$ varlığına bağlı olduğu (negatif ilişkili) ortaya konmuştur [75]. Bu çalışmada ise PRE değerlerinin toprak fosfor içeriğiyle ilişkisi bulunamamıştır. Fakat Çin'de ormanlık alanlarda yapılan çalışmalarda ise PRE değerinin toprak P içeriğiyle negatif ilişki olduğu belirlenmiştir [76]. Toprak pH'sı ve EC değerleri ile olan pozitif ilişkiyi ise türün ekolojik üstünlüğüne bağlanabilir. Yapılan çalışmalarda, A. altissima'nın ölü örtüsünün hızlı ayrışması veya türün toprak $\mathrm{P}$ içeriğine bağımlılığının olmamasından kaynaklanabilir. Hayes ve arkadaşları, toprak P içeriği ile toprak pH'sının pozitif ilişkili olduğunu ortaya koymuştur [74]. Bu çalışmada istatistiksel analizlerden elde edilen sonuçlar değerlendirildiğinde; fosfor rezorbsiyon değerlerinin yüksek oluşunun toprağın $\mathrm{pH}$ özellikleriyle ilişkili olduğu söylenebilir. Toprak elektriksel iletkenliği ile olan ilişkisi ise Nasrin ve arkadaşları tarafından yapılan çalışma ile uygunluk göstermektedir. Nasrin ve arkadaşları topraktaki Na konsantrasyonunun azot ve fosfor rezorbsiyonuyla pozitif ilişkili olduğunu bulmuşlardır [77]. Yine mangrov ormanlarında yapılan çalışmalarda, P rezorbsiyonunun tuzlulukla ilişkisinin daha yüksek olduğu tespit edilmiştir [78]. 
Türlerin rezorbsiyon yeteneklerini ortaya koyan bir diğer yöntem ise senesens yapraklarda kalan besin miktarıdır. A. altissima'nın NRP değerlerinin 12.56-14.06 mg/g, PRP değerlerinin ise 1.63-1.83 mg/g arasında değiştiği bulunmuştur. $\mathrm{Bu}$ değerler yüzdeye çevrildiğinde; $\mathrm{N}$ için \%1.26-1.41, fosfor için ise \%0.13-0.14 arasında rezorbsiyon yeterlilik değerlerine ulaşılmaktadır. Killingbeck, $\mathrm{N}$ tespit etmeyen türler için $\mathrm{N}$ rezorbsiyon yeterlilik sınırını \%0.87, P rezorbsiyon yeterlilik sınır oranını ise $\% 0.06$ olarak belirlemiştir [33]. Bu değerlere göre $A$. altissima $\mathrm{N}$ bakımından yüksek rezorbsiyon yeterliliğine sahipken, $\mathrm{P}$ için rezorbsiyon yeterliliğinin düşük olduğu görülmektedir.

\section{SONUÇLAR}

Sonuç olarak, bu çalışmada Türkiye için yabancı istilacı bir tür olan A. altissima'nın azot ve fosfor için besin kullanım stratejileri, SLA, LMA, yaprak N:P oranı ve toprak özellikleri (pH, N ve P içeriği, EC) ile birlikte açıklanmıştır. Elde edilen sonuçlara göre ekolojik açıdan hem firsatçı hem de besin koruma stratejisini sergileyen A. altissima yüksek $\mathrm{N}$ rezorbsiyon yeteneğine $\left(\mathrm{NRE}=\%\right.$ 71.60-74.35, $\left.\mathrm{NRE}_{\mathrm{mlcf}}=\% 73.39-75.97\right)$ sahiptir ve bu durumun topraktaki yüksek azot içeriği (\%1.03-1.39) ile de değişmemiştir. Türün fosfor elementi yönünden düşük (\%0.013-0.018) içerikli topraklarda gelişebilmesi de P rezorbsiyon değerlerinden (PRE= \% 41.08-47.70 $\mathrm{PRE}_{\mathrm{mlcf}}=\%$ 44.79-50.99) anlaşılmaktadır. Ayrıca bulunduğu toprakların N bakımından zenginleşmesini sağlayan A. altissima, yüksek rekabet gücü sayesinde de topraktan N alımında diğer türlere üstünlük sağlamaktadır. Türle ilgili yapılan önceki çalışmalarda düşük $\mathrm{N}$ içerikli toprakların gelişimlerini olumsuz etkilemediği dikkate alındığında bu çalışmada yüksek $\mathrm{N}$ içerikli topraklarda $\mathrm{N}$ rezorbsiyon oranının az olması beklenirken daha yüksek çıkmıştır. Bu durum türün hem topraktaki azota karşı hem de rezorbsiyon yeteneğini yönünden çevresindeki bitkilere göre daha avantajlı olduğunu ortaya koymaktadır.

\section{KAYNAKLAR}

[1] Vitousek, P. (1982). Nutrient cycling and nutrient use efficiency. American Naturalist, 119, 553-572.

[2] Aerts, R. (1996). Nutrient resorption from senescing leaves of perennials: are there general patterns? Journal of Ecology, 84, 597-608.

[3] Aerts, R., \& Chapin, F. S. (2000). The mineral nutrition of wild plants revisited: A re-evaluation of processes and patterns. Advances of Ecological Research, 30, 1-67.

[4] Chabot, B. F., \& Hicks, D. J. (1982). The ecology of leaf life span. Annual Review of Ecology Systematics, $13,229-259$.

[5] Lin, P., \& Wang, W. (2001). Changes in the leaf composition, leaf mass and leaf area during leaf senescence in three species of mangroves. Ecological Engineering, 16, 415-424.

[6] Tecimen, H. B., \& Makineci, E. (2007). Ağaçlarda besin maddelerinin yeniden taşınması olayı ve ekolojik yönü. SDÜ Orman Fakültesi Dergisi, 1, 134-145.

[7] Darrah, P. R. (1993). The rhizosphere and plant nutrition: a quantitative approach. Plant and Soil, 155(156), $1-20$.

[8] Marschner, H. (2011). Marschner's mineral nutrition of higher plants. Academic Press, USA, 672.

[9] Hinsinger, P. (1998). How do plant roots acquire mineral nutrients? Chemical processes involved in the rhizosphere. Advances in Agronomy, 64, 225-265.

[10] Hagen-Thorn, A., Varnagiryte, I., Nihlgård, B., \& Armolaitis, K. (2006). Autumn nutrient resorption and losses in four deciduous forest tree species. Forest Ecology and Management, 228, 33-39.

[11] Oleksyn, J., Reich, P. B., Zytkowıak, R., Karolewski, P., \& Tjoelker, M. G. (2002). Needle nutrients in geographically diverse Pinus sylvestris L. populations. Annals of Forest Science, 59, 1-18. 
[12] Ordoñez, J. C., Van Bodegom, P. M., Witte, J. P. M., Wright, I. J., Reich, P. B., \& Aerts, R. (2009). A global study of relationships between leaf traits, climate and soil measures of nutrient fertility. Global Ecology and Biogeography, 18(2), 137-149.

[13] Maire, V., Wright, I. J., Prentice, I. C., Batjes, N. H., Bhaskar, R., van Bodegom, P.M., Cornwell, W. K., Ellsworth, D., Niinemets, Ü., Ordonez, A., Reich, P. B., \& Santiago, L. S. (2015). Global effects of soil and climate on leaf photosynthetic traits and rates. Global Ecology and Biogeography, 24(6), 706-717.

[14] Güsewell, S., \& Koerselman, W. (2002). Variation in nitrogen and phosphorus concentrations of wetland plants. Perspectives in Plant Ecology, Evolution and Systematics, 5, 37-61.

[15] Olde Venterink, H., Wassen, M. J., Verkroost, A. W. M., \& De Ruiter, P. C. (2003). Species richnessproductivity patterns differ between N, P, and K limited wetlands. Ecology, 84(8), 2191-2199.

[16] Kobe, R. K., Lepczyk, C. A., \& Iyer, M. (2005). Resorption efficiency decreases with increasing green leaf nutrients in a global data set. Ecology, 86, 2780-2792.

[17] Vergutz, L., Manzoni, S., Porporato, A., Novais, R. F., \& Jackson, R. B. (2012). Global resorption efficiencies and concentrations of carbon and nutrients in leaves of terrestrial plants. Ecological Monographs, 82, 205-220.

[18] Brant, A. N., \& Chen, H. Y. (2015). Patterns and mechanisms of nutrient resorption in plants. Critical Reviews in Plant Sciences, 34(5), 471-486.

[19] Huston, M. A. (2012). Precipitation, soils, NPP, and biodiversity: Resurrection of Albrecht's curve. Ecological Monographs, 82, 277-296.

[20] Anacker, B. L. (2011). Phylogenetic patterns of endemism and diversity. University of California Press, Berkeley, 49-70.

[21] Drenovsky, R. E., Koehler, C. E., Skelly, K., \& Richards, J. H. (2013). Potential and realized nutrient resorption in serpentine and non-serpentine chaparral shrubs and trees. Oecologia, 171, 39-50.

[22] Eckstein, R. L., Karlsson, P. S., \& Weih, M. (1999). Leaf life span and nutrient resorption as determinants of plant nutrient conservation in temperate - arctic regions. New Phytologist, 143, 177-189.

[23] Yuan, Z., \& Chen, H. Y. H. (2009). Global trends in senesced-leaf nitrogen and phosphorus. Global Ecology and Biogeography, 18, 532-542.

[24] Wang, G. (2007). Leaf trait co-variation, respond and effect in a chronosequence. Journal of Vegetation Science, 18(4), 563-570.

[25] Reich, P. B., Walters, M. B., \& Ellsworth, D. S. (1992). Leaf lifespan in relation to leaf, plant, and stand characteristics among diverse ecosystems. Ecological Monographs, 62, 365-392.

[26] Cornelissen, J. H. C., Lavorel, S., Garnier, E., Diaz, S., Buchmann, N., Gurvich, D. E., Reich, P. B., ter Steege, H., Morgan, H. D., van der Heijden, M. G. A., Pausas, J. G., \& Poorter, H. (2003). A handbook of protocols for standardized and easy measurement of plant functional traits worldwide. Australian Journal of Botany, 51(4), 335-380.

[27] Grime, J. P. (1998). Benefits of plant diversity to ecosystems: immediate, filter and founder effects. Journal of Ecology, 86(6), 902-910.

[28] Wright, I. J., Reich, P. B., Cornelissen, J. H. C., Falster, D. S., Garnier, E., Hikosaka, K., Lamont, B. B., Lee, W., Oleksyn, J., Osada, N., Poorter, H., Villar, R., Warton, D. I., \& Westoby, M. (2005). Assessing the generality of global leaf trait relationships. New Phytologist, 166(2), 485-496. 
[29] Keddy, P. A. (2001). Competition. Springer-Verlag, Berlin, 552.

[30] Reich, P. B., Wright, I. J., Cavender-Bares, J., Craine, J. M., Oleksyn, J., Westoby, M., \& Walters, M. B. (2003). The evolution of plant functional variation: traits, spectra, and strategies. International Journal of Plant Sciences, 164(S3), 143-164.

[31] Westoby, M., \& Wright, I. J. (2006). Land-plant ecology on the basis of functional traits. Trends in Ecology \& Evolution, 21, 261 .

[32] Distel, R. A., Moretto, A. S., \& Didoné, N. G. (2003). Nutrient resorption from senescing leaves in two Stipa species native to Central Argentina. Austral Ecology, 28, 210-215.

[33] Killingbeck, K. T. (1996). Nutrients in senesced leaves: keys to the search for potential resorption and resorption proficiency. Ecology, 77, 1716-1727.

[34] Killingbeck, K. T. (2004). Nutrient resorption. Academic Press, San Diego, 215-226.

[35] Albouchi, F., Hassen, I., \& Casabianca, H. (2013). Phytochemicals, antioxidant, antimicrobial and phytotoxic activities of Ailanthus altissima (Mill.) Swingle leaves. South African Journal of Botany, 87, $164-174$

[36] Harris, P. T., Cannon, G. H., Smith, N. E., \& Muth, N. Z. (2013). Assessment of plant community restoration following Tree-of-Heaven (Ailanthus altissima) control by Verticillium albo-atrum. Biological Invasions, 15, 1887-1893.

[37] Knüsel, S., Conedera, M., Rigling, A., Fonti, P., \& Wunder, J. (2015). A tree-ring perspective on the invasion of Ailanthus altissima in protection forests. Forest Ecology and Management, 354, 334-343.

[38] Meng, P. P., Pei, H. Y., Hu, W. R., Liu, Z. D., Li, X. Q., \& Xu, H. Z. (2015). Allelopathic effects of Ailanthus altissima extracts on Microcystis aeruginosa growth, physiological changes and microcystins release. Chemosphere, 141, 219-226.

[39] Bao, Z., \& Nilsen, E. T. (2015). Interactions between seedlings of the invasive tree Ailanthus altissima and the native tree Robinia pseudoacacia under low nutrientconditions. Journal of Plant Interactions, 10, 173184.

[40] Li, M., Du, N., Guo, X., Yu, T., Zhao, S., \& Guo, W. (2017). Nitrogen deposition does not reduce water deficit in Ailanthus altissima seedlings. Flora, 233, 171-178.

[41] Boerner, R. E. J., \& Koslowsky, S. D. (1989). Microsite variations in soil chemistry and nitrogen mineralization in a beechmaple forest, Soil Biology and Biochemistry, 21, 795-801

[42] Milla, R., Maestro-Martínez, M., \& Montserrat-Martí, G. (2004). Seasonal branch nutrient dynamics in two Mediterranean woody shrubs with contrasted phenology. Annals of Botany, 93, 671-680.

[43] Bremner, J. M. (1960). Determination of nitrogen in soil by the Kjeldahl method. The Journal of Agricultural Science, 55(1), 11-33.

[44] Allen S. E., Grimshaw H. M., Parkinson J. A., Quarmby C., \& Roberts J. D. (1986). Chemical Analysis, in: Chapman S.B. (Ed.), Methods in Plant Ecology. Blackwell Scientific Publications, Oxford, 411-466.

[45] Balkovič, J., Kollár, J., \& Šimonovič, V. (2012). Experience with using Ellenberg’s R indicator values in Slovakia: Oligotrophic and mesotrophic submontane broad-leaved forests. Biologia, 67(3), 474-482.

[46] Kılınç, M., Kutbay, H. G., Yalçın, E., \& Bilgin, A. (2006). Bitki Ekolojisi ve Bitki Sosyolojisi Uygulamalart. Palme yayıncılik, Ankara, 370. 
[47] Bray, R. H., \& Kurtz, L. T. (1945). Determination of total, organic, and available forms of phosphorus in soils. Soil Science, 59(1), 39-46.

[48] Irmak, A. (1954). Arazide ve Laboratuarda Toprağın Araştırılması Metotları. İstanbul Üniversitesi Orman Fakültesi Yayınları, İstanbul, 150.

[49] Kacar, B. (2009). Toprak Analizleri, 2. Baskı. Nobel Yayınları, Ankara, 467.

[50] Sağlam, M. T. (2012). Toprak ve Suyun Kimyasal Analiz Yöntemleri. Namık Kemal Üniversitesi Ziraat Fakültesi Yayınları, Tekirdağ, 154.

[51] Gülçur, F. (1974). Toprağın Fiziksel ve Kimyasal Analiz Metodları. İstanbul Üniversitesi Orman Fakültesi Yayınlar1, İstanbul, 225.

[52] Eruz, E. (1979). Toprak tuzluluğu ve bitkiler üzerindeki genel etkileri. Journal of the Faculty of Forestry, 112-120.

[53] van Heerwaarden L. M., Toet S., \& Aerts R. (2003). Current measures of nutrient resorption efficiency lead to a substantial under estimation of real resorption efficiency: facts and solutions. Oikos, 101, 664-669.

[54] Anonim (2017). SPSS 17.0 for Windows. SPSS Inc., New York.

[55] González-Muñoz, N., Castro-Díez, P., \& Parker, I. M. (2013). Differences in nitrogen use strategies between native and exotic tree species: predicting impacts on invaded ecosystems. Plant and Soil, 363(1-2), 319-329.

[56] Swan, C. M., \& Healey, B. (2008). The role of native riparian tree species in decomposition of invasive tree of heaven (Ailanthus altissima) leaf litter in an urban stream. Ecoscience, 15(1), 27-35.

[57] Castro-Díez, P., González-Muñoz, N., Alonso, A., Gallardo, A., \& Poorter, L. (2009). Effects of exotic invasive trees on nitrogen cycling: a case of study in Central Spain. Biological Invasions, 11, 1973-1986.

[58] Alonso, A., González-Muñoz, N., \& Castro-Díez, P. (2010). Comparison of leaf decomposition and macro invertebrate colonization between exotic and native trees in a freshwater ecosystem. Ecological Research, $25,647-653$.

[59] Lima, A. L. D. S., Zanella, F., Schiavianto, M. A., \& Haddad, C. R. B. (2006). N availibility and mechanisms of $\mathrm{N}$ conservation in deciduoud and semideciduous tropical forest legume trees. Acta Botanica Brasilica, 20, 625-632.

[60] Hongua, H. E., Bleby, T. M., Veneklaas, E. J., \& Lambers, H. (2001). Dinitrogen-fixing Acacia species from phosphorus-improverishes soils resorb leaf phosphorus efficiently. Plant, Cell and Environment, 34, 2060-2070.

[61] Sürmen, B., Kutbay, H. G., Kiliç, D. D., \& Sürmen, M. (2014). Foliar resorption in nitrogen-fixing and nonfixing species in a swamp forest in northern Turkey. La Revue d'Écologie (La Terre et La Vie), 69(4), 318327.

[62] Kutbay, H. G., \& Ok, T. (2003). Foliar N and P resorption and nutrient levels along an elevation gradient in Juniperus oxycedrus L. subsp. macrocarpa (Sibth. \& Sm.) Ball. Annals of Forest Science, 60, 449-454.

[63] Surmen, B. (2012). Hacıosman Subasar Ormanında bazı azot tespiti yapan ve yapmayan ăgaç ve çalı türlerinde yaprak rezorbsiyonu. Yüksek Lisans Tezi, Ondokuz Mayıs Üniversitesi, Fen Bilimleri Enstitüsü, Samsun. 
[64] Sohrt, J., Herschbach, C., \& Weiler, M. (2018). Foliar P-but not N resorption efficiency depends on the Pconcentration and the N:P ratio in trees of temperate forests. Trees, 32(5), 1443-1455.

[65] Gravano, E., Giulietti, V., Desotgiu, R., Bussotti, F., Grossoni, P., Gerosa, G., \& Tani, C. (2003). Foliar response of an Ailanthus altissima clone in two sites with different levels of ozone-pollution. Environmental Pollution, 121(1), 137-146.

[66] Jurik, W. T. (1986). Temporal and spatial patterns of specific leaf weight in successional northern hardwood tree species. American Journal of Botany, 73(8), 1083-1092.

[67] Walters, M. B., Kruger, E. L., \& Reich, P. B. (1993). Growth, biomass distribution and CO2 exchange of northern hardwood seedlings in high and low light: relationships with successional status and shade tolerance. Oecologia, 94, 7-16.

[68] Bussotti, F. (2008). Functional leaf traits, plant communities and acclimation processes in relation to oxidative stress in trees: a critical overview. Global Change Biology, 14, 2727-2739.

[69] Sardans, J., \& Peñuelas, J. (2013). Plant-soil interactions in Mediterranean forest and shrublands: impacts of climatic change. Plant and Soil, 365, 1-33.

[70] Yılmaz, H., Kutbay, H. G., \& Sürmen, B. (2019). Öksin bölgesinde plantasyon yapılan ve tahribata uğramamış ormanlarda bir Akdeniz türünün (Arbutus unedo) yaprak karakterleri. Eurasian Journal of Biological and Chemical Sciences, 2(2), 67-72.

[71] Petruzzellis, F., Nardini, A., Savi, T., Tonet, V., Castello, M., \& Bacaro, G. (2018). Less safety for more efficiency: water relations and hydraulics of the invasive tree Ailanthus altissima (Mill.) Swingle compared with native Fraxinus ornus L. Tree physiology, 39(1), 76-87.

[72] Sürmen, B., Kutbay, H. G., Çakmak, A., \& Yılmaz, H. (2016). Comparison of leaf traits (SLA And LMA) on different populations of Alcea apterocarpa. Hacettepe Journal of Biolology and Chemistry, 44(2), 125131.

[73] Vila, M., Tessier, M., Suehs, C. M., Brundu, G., Carta, L., Galanidis, A., Lambdon, P., Manca, M., Medail, F., Moragues, E., Traveset, A., Troumbis, A. Y., \& Hulme, P. E. (2006). Local and regional assessment of the impacts of plant invaders on vegetation structure and soil properties of Mediterranean islands. Journal of Biogeography, 33, 853-861.

[74] Hayes, P., Turner, B. L., Lambers, H., \& Laliberté, E. (2014). Foliar nutrient concentrations and resorption efficiency in plants of contrasting nutrient-acquisition strategies along a 2-million year dune chronosequence. Journal of Ecology, 102, 396-410.

[75] Zhang, H., Guo, W. H., Yu, M. K., Wang, G. G., \& Wu, T. G. (2018). Latitudinal patterns of leaf N, P stoichiometry and nutrient resorption of Metasequoia glyptostroboides along the eastern coastline of China. Science of the Total Environment, 618, 1-6.

[76] Tang, L., Han, W., Chen, Y., \& Fang, J. (2013). Resorption proficiency and efficiency of leaf nutrients in woody plants in eastern China. Journal of Plant Ecology, 6, 408-417.

[77] Nasrin, S., Hossain, M., \& Rahman, M. M. (2019). Adaptive responses to salinity: nutrient resorption efficiency of Sonneratia apetala (Buch.-Ham.) along the salinity gradient in the Sundarbans of Bangladesh. Wetlands Ecology and Management, 27(2-3), 343-351.

[78] Medina, E., Fernandez, W., \& Barboza, F. (2015). Element uptake, accumulation, and resorption in leaves of mangrove species with different mechanisms of salt regulation. Web Ecology, 15(1), 3-13. 